trocnemius from soleus; matter very thin, fetid, and discoloured; two incisions made down to it; water-dressing changed twice a day.

December 1st.-Wound in the thigh nearly well; abscess in the calf discharges freely; pus healthy; a more stimulating dressing, and a small abscess in the groin, below Poupart's ligament.

March 6 th.-He left the ship.

\section{A MEDICAL BILL.}

T'o the Editor of The Lancet.

Sir,- - In all the plans hitherto adopted for procuring a combination of professional men in the cause of medical reform, there have been so many difficulties to contend with, that I am not surprised at their failure. It is not; however, necessary for me now to enter into an explanation of my opinions. I have only to repeat a suggestion made to you some wonths back,-a suggestion to which you then kindly lent your aid. I' again solicit your assistance, and should you approve of the accompanying address, which $I$, an humble member of the profession, offer to my brethren, you would oblige me by giving it a place in your journal.

I cannot but feel that if you present a Bill to the House having the objects you have described to us, and at the time carry your journal in your hand, containing the names of the bulk of the profession, a stronger or more forcible petition could not be presented to Parliament.

Wandsworth, March, 1846.

am, Sir, your obedient servant JoHN Grove.

\section{An Adpress to the Medical Practitioners of} Great Britain and Ireinand.

By Joun Grove, M.R.C.S. Eng., L.S.A., Surgeon to the Wandsworth and Clapham Únion.

Gentuemen,-Early, during this session, Mr. Wakley has told you he intends bringing in a bill for the better regulation of the practice of physic and surgery.

His scheme, of which you have been in possession for some months, offers you everything which an enlightened mind could suggest or desire. If this scheme should be enacted into law, you would be emancipated from the professional bondage under which you have so long laboured, you would shake off the trammels and ignominy of hybrids or professional traders, your legitimate position would be obtained, and you would stand before the world, as you ought, a body of upright, intelligent men, having a title worthy your calling, a character worthy your title.

He has told you his intentions some months since, and I doubt not he is ready to take upon himself the arduous task of framing, and bringing in, a bill for an object which has hitherto baffled all who have encountered it.

Let us, then, for once, be unanimous; let us give Mr. Wakley and his measure all the support and encouragement in our power.

To the elder nembers of the profession who have attained any eminence, I say, that very few of you have not, at some time or other, received your due inced of praise in the pages of Tris LANCET. To the Editor of that journal, in many instances, much of your success is to be attributed: he has extolled you when you deserved praise; the public have by him been taught to seek your professional assistance, by having their attention directed to your particular attainments; and for this, I sav, he deserves your gratitude and esteem.

To those who are rising into eminence, I say, he will award you vour deserts, and assist you in your honourable and praisewortly exertions; perhaps even he has already breathed on you the vitalizing influence of editorial encouragement.

To the junior members of the profession, I say, in Mr. Wakley you have a veteran for your champion, who knows the difficulties of his position and the abstacles he has to overcome. Place implicit confidence in his generalship and integrity, and be contented to serve in his ranks; he will not lead you to a defeat, but bring you off victorious, if you will but fight with him faithfully.

To all of you, collectively, I say, -when you have had professional differences, when you have been threatened with new oppressions, when you have wanted an advocate, Mr. Wakley has ever been your impartial friend, the steady upholder of your privileges, and your eloquent pleader.

I tell you, through him, your only representative in the House of Commons, you must make your 20,000 voices heard; through him alone will they reach the government in harmony.
If you speak thus, you will find listening ears, attentive minds; and willing hearts, for your cause. To this end let the Editor of Th LanceT, when he brings in his Bill, carry with him a petition, containing our legion of names, with the cause we advocate; no other matter should be inserted.

What petition, I ask, could possibly carry such weight as this? It would be a permanent record, moreover, of the unanimity, perseverance, and determination of medical men in 1846.

I have a firm conviction, if this were done, that our great medical reformer would soon be enabled to say that his labour had not been in vain.

\section{ASSOCIATED SURGEONS, FREEMASONS' TAVERN} Wednesday, Marce 4.

Aт a meeting of the committee,-G. BоттомLex, Esq., of Croydon, in the chair, - the minutes of the former meeting having been read, the honorary secretary stated, that in compliance with the resolution passed at the last meeting, he had written to the gentlemen named as delegates to the council. That a request was then made, through the president, for an interview with the council, which was readily acceded to, and on the 30th of January the meeting took place, of which a report was given in THE LANCET of February 7th; that as yet no information had been given by the council as to the probability of their agreeing to the suggestions contained in that memorial, but that there was reason to think the subject was still under discussion.

The Secretary stated, that since the presentation of that memorial, one numerously signed* had been forwarded to the council from the surgeons of Bath, and that the surgeons of Gloucester had petitioned her Majesty to the same effect.

The Treasurer reported that he had received the following additional subscriptions to the funds of the Association, besides several smaller sums :-

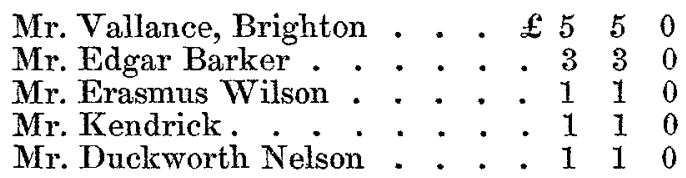

Resolved, That the best thanks of the Committee be presented to the above gentlemen for their liberal subscriptions.

The Secretary reported, that on applying to Mr. Churchill for the account due for advertisements inserted by the Association in Trme Lancet, he had received a note, stating that the Editor had directed that no charge would be made for them.

Moved by Mr. Arraham, seconded by Mr. Lewis, and resolved, - That the best thanks of the Committee be presented to Mr. WAKLEY for his liberality in giving insertion to the several advertisements referred to free of expense.

A discussion then ensued as to the propriety of passing a resolution condemnatory of the late exhibition at the College, in the course of which both the Orator and his Oration were freely canvassed, and the Committee were unanimously of opinion, that as a vote of censure had already been passed by the Council on that indecent attack on the members of the College, and that as it is with the Council as a body that this Association has alone anything to do, it would not be desirable that any formal notice should be taken of the subject by this Committee.

The question was then mooted, whether it would be desirable that the Committee should take part. in the endeavour to establish a Faculty of Medicine, as proposed by some other of the Medical Associations; but it was generally felt that as this Association had been instituted expressly for the purpose of endeavouring to obtain for the Members of the College of Surgeons enfranchisement in that institution, the Committee would not be justified in taking part in any attempt which might interfere with that object.

The Committee separated at a late hour.

\section{THE BRISTOL MEDICAL SCHOOL}

\section{To the Editor of The Lancet.}

SrR,-The points at issue between the Bristol Medical School and myself are few, but they each require a straightforward reply. The Committee "express surprise, \&c."; I contend, not only that $I$ have a right, but that it is my duty, to prefer a charge upon the authority of my pupil. My professional brethren in this city look with very great interest to 
the gettlement of this question, and they also wonder how the faculty ean excuse the denial contained in their letter of Dec. 22nd, which was positive and without any qualification; that denial has not been withdrawn, so that at present I may, from my renewal of the charge, be supposed to have committed a wilful and deliberate falsehood,-I therefore call upon them, as men of honour, either to withdraw their denial, or otherwise to confirm it by proof taken from their own books: should they fail to do so, they must necessarily place themselves under that stigma which at present attaches to me. The animus exhibited in Mr. Prichard's letter is exceedingly amusing. When I sent my first letter to the school, charging the lecturers with the omission of two lectures, with their dates, they turned to the register to see if my pupil had been regular in his attendance. In the same book they might have noticed their own omissions, but they did not wish to see them. When they had found what they wanted, they then "believed my allegation to be unwarranted." Such an attempt to injure that pupil in the eyes of the public is indeed mean. In justice to him I will state, that his certificates for the past two years run thus:- - seven courses of lectures, very diligently attended; three diligently attended, and two attended.

I am, Sir, your obedient servant,

St. James's-square, Bristol, March, 1846.

J. G. LANSDOWN.

\section{THE “ RENEGADE ORATOR."}

Amova the numerous letters we have received on the subject of the flagrant "Oration" has been one from which we extract the following passage:--

"If the ground on which the Hunterian Oration is delivered be not hallowed, the occasion ought at least to have been so. Amidst all the differences of the profession it formed a little oasis, wherein, whatever their opinions might otherwise have been, men could meet in the enjoyment of common sentiments of united feelings; and all alike join in admiration of the genius, and gratitude for the labours, of John Hunter.

The place and the occasion has been desecrated by the delivery of one of the very worst Orations, as such, that I ever perused;- by the revival of excitement, which was gradually subsiding into something like patient consideration of our grievances, and by insult and abuse, so coarse and ungentlemanly, as to be, I should think, wholly unexampled. It may be proper, perhaps, to wait a little to see how the Council will dispose of a case so disgracefully special."

\section{THE OUTLAWRY OF SURGEONS.}

\section{To the Editor of The LANCET.}

Srr,--You have not yet sufficiently noticed a certain proposition of the Council of the Royal College of Surgeons of England: if it were a harmless display of their vanity and folly, it certainly would not deserve to be mentioned in your valuable publication, and might safely be left, like other simple absurdities, to be laughed at. I allude to the new-fangled project that Fellows of the College shall not be enabled to recover fees for surgery and surgical attendances. Now this is an unbusiness-like, and would prove an injurious by-law, as the unprincipled part of society will thereby obtain another advantage over their professional attendants, of which they possess too many already.

Now we can suppose this by-law to be made with no other notion than the ridiculous one of elevating themselves and their newly-made fellows to the imaginary rank of physicians: but, although between physicians and the public the established custom of receiving fees is a proper one, yet it cannot so well apply to surgeons, as it will manifestly appear, on a little consideration, that the circumstances under which the attendances of the two are required, do in reality differ as much as the services rendered. When a general practitioner is in attendance, the caprice or vanity of some of the patient's friends may induce them to urge a physician being "called in;" and except when the practitioner himself is anxious for such a step, it is almost a voluntary act on their part. But with regard to surgical services, (especially the purely surgicai services on which the Council plume themselves, ) the case is widely different. In the majority of instances a surgeon is sent for when some bodily injury has been stastained-when surgical assistance must instantly be had-and, notwithstanding the apparent good circumstances of the patient, he may be one of those unprincipled scamps who live by cheating all they can, in what this sort of people call "keeping up their respectability;" wlio, in fact, pay as few bills as possible, and their medical man's more rarely, if at all, than any others: the accident has occurred, according to their ordinary talk, " at really the most unfortunate time possible," and for a very good reason no fees are offered to the Fellow who, in the alarm and hurry, has been summoned to attend : so he continues for weeks, and perhaps for months, in some or other such labour and work as follow: strapping, plastering, bandaging, splinting, or bleeding, leeching, fomenting, poulticing, arterycompressing, blood-staunching, lint-dosseling, flesh-cutting, hair-clipping, skin-sewing, joint-reducing, limb-extending, bone-setting, sawing, or clipping, with various other manual operations, besides prescribing; and after all this the Fellow is not to have the power of legally enforcing payment as heretofore! He may be, and doubtless will be, choused out of his hardly-earned recompence by the absurd regulation of his own College! Civilly, and with polite excuses at first; but rely upon it, that the equally civil and polite requests of the pure surgeon for payment, will be met, at last, with jars and exultations.

It is also much to be regretted, Mr. Editor, that these "doings" have not been without their effect, reverentially be it spoken, in another place. It is said that the Master and Court of Assistants of the Worshipful Company of the Barber Surgeons have been thereby excited to a rather vexatious display of rivalry; boasting, and with truth, that their Charter was granted them by the same many-wived monarch who conferred such valuable privileges on the Royal College of Physicians; and in imitation of their quondam brethren, the now Royal College of Surgeons of England, they intend, also, to apply for an amplification of their Charter, that they may be styled, henceforth, the Royal Company of Barber Surgeons of all England,--that they may constitute themselves and their hangers-on, and two or three hundred smart curlyheaded young fellows just out of their apprenticeship, whom they may please to nominate, into a sort of aristocracy, to be called "Pure Barber Surgeons," who are to be distinguished from the commonalty, who are pediculi and porrigo, and sell perfumes and crystallized pomatum, and with respect to whom there shall be also a distinguishing regulation, that they shall receive the fees for hair cutting and powdering, curling, and dressing, together with shaving, \&c., instanter, and that none of them shall be able to recover charge for purely tonsorial services.

Jan. 1846 .

Aristogrines.

THE BRISTOL ASSOCIATION OF SURGEONS.

The Mrmorial from this Association, forwarded to Messrs. Mrues, Berkelex, and $\mathrm{W}_{\mathrm{AKLEY}}$, for presentation to Sir J JMES Graham, has been received. Sir James has appointed this day, Saturday, March Tth, for seeing the deputation and accepting the Memorial. This important document has been signed by nearly one thousand members of the College of Surgeons.

\section{NEWS OF THE WEEK.}

INSANITY AND QuACKERY.-Who can expect that imposture and quackery will meet the proper punishment of their sins, when such insane puffs as the following, extracted from the advertising columns of The Times, of Jan. 1个th, are allowed space in influential public journals? How extravagant is the reliance which the quacks place on the gullibility of the English public, when such an absurdity is expected to find geese amongst them for its authors to pluck:-

\section{THE ACKERLEIAN PURIFICATION of the}

BONES, as liquifying the chilled marrow by flame-light electricity, causing reflow of joint-oil Inbrication, for stiffened joints, ossific gout, rheumatism, cancer'os' and ulcer'os' contractions, without confinement or alteration of diet. Sun-like expanding, as in plant animal physiology, the nervous fibrilsthese respirative tubes being incorporeal for aireal circulation, giving cartilagen'os' expansion for sleep.-5, S- street, Piccadilly. Consultations, 6 to $8 \mathrm{a} . \mathrm{m}$. and 11 to $1 \mathrm{p.m}$.

WILLIAM LAwrexce.-The bust of this person, which had for some time previously occupied a very prominent position in the library of the Roval Medical and Chirurgical Suciety, was, previously to the amiversarr meeting on Monday last, removed and taken out of sight of the members. 'This act of the Comcil of the Society was spoken of as indicating a proper respect for their constituents by many of the gentlemen present. 